\title{
Activation of human mast cells by retrocyclin and protegrin highlight their immunomodulatory and antimicrobial properties
}

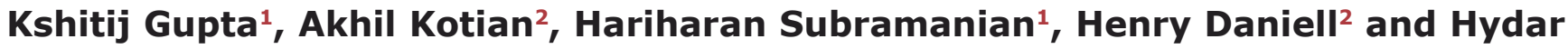 \\ Ali $^{1}$ \\ ${ }^{1}$ Department of Pathology, School of Dental Medicine, University of Pennsylvania, Philadelphia, PA, USA \\ 2 Department of Biochemistry, School of Dental Medicine, University of Pennsylvania, Philadelphia, PA, USA \\ Correspondence to: Hydar Ali, email: alih@upenn.edu
}

Henry Daniell, email: hdaniell@upenn.edu

Keywords: antimicrobial peptides, mast cells, retrocyclin, protegrin, chloroplast, MrgX2, Immunology and Microbiology Section, Immune response, Immunity

Received: July 04, $2015 \quad$ Accepted: August 30, $2015 \quad$ Published: September 10, 2015

This is an open-access article distributed under the terms of the Creative Commons Attribution License, which permits unrestricted use, distribution, and reproduction in any medium, provided the original author and source are credited.

ABSTRACT

Preclinical evaluation of Retrocyclins (RC-100, RC-101) and Protegrin-1 (PG-1) antimicrobial peptides (AMPs) is important because of their therapeutic potential against bacterial, fungal and viral infections. Human mast cells (HMCs) play important roles in host defense and wound healing but the abilities of retrocyclins and protegrin-1 to harness these functions have not been investigated. Here, we report that chemically synthesized RC-100 and PG-1 caused calcium mobilization and degranulation in HMCs but these responses were not blocked by an inhibitor of formyl peptide receptor-like 1 (FPRL1), a known receptor for AMPs. However, RC-100 and PG-1 induced degranulation in rat basophilic leukemia (RBL-2H3) cells stably expressing Mas related G protein coupled receptor X2 (MrgX2). Chemical synthesis of these AMPs is prohibitively expensive and post-synthesis modifications (cyclization, disulfide bonds, folding) are inadequate for optimal antimicrobial activity. Indeed, we found that synthetic RC-100, which caused mast cell degranulation via MrgX2, did not display any antimicrobial activity. Green-fluorescent protein (GFP)-tagged RC-101 (analog of RC-100) and GFP-tagged PG-1 purified from transgenic plant chloroplasts killed bacteria and induced mast cell degranulation. Furthermore, GFPPG1 bound specifically to RBL-2H3 cells expressing MrgX2. These findings suggest that retrocyclins and protegrins activate HMCs independently of FPRL1 but via MrgX2. Harnessing this novel feature of AMPs to activate mast cell's host defense/wound healing properties in addition to their antimicrobial activities expands their clinical potential. Low cost production of AMPs in plants should facilitate their advancement to the clinic overcoming major hurdles in current production systems.

\section{INTRODUCTION}

Antibiotics have been used for treatment of microbial infections since the early 1900 s but emergence of multidrug resistant strains of microbes poses a tremendous public health concern globally [1]. Thus, there is an urgent need to develop novel therapy for the treatment of infectious diseases caused by antibiotic resistant organisms. Cationic antimicrobial peptides (AMP), also known as host defense peptides (HDPs) such as the cathelicidin LL-37 and human $\beta$-defensins (hBDs) have the potential to be utilized as antimicrobial agents [2-4]. In addition to their direct antimicrobial activity, LL37 and hBDs display immunomodulatory properties which include the recruitment and activation of immune cells such as mast cells, neutrophils, monocytes and $\mathrm{T}$ cells [59]. These AMPs also modulate angiogenesis and promote wound healing [10-12]. In addition, many AMPs cause red blood cell lysis and display cytotoxic activity against immune and non-immune cells $[13,14]$. Great strides have 
been made in recent years in identifying and optimizing AMPs for lower toxicity with greater stability/activity, which can also harness the immune system for therapeutic benefits $[15,16]$.

A family of AMPs known as $\theta$-defensins is found in leukocytes of rhesus macaques [17]. These cyclic octadecapeptides are stabilized by three disulfide bonds, display antifungal, antibacterial, antiviral activities and are thought to play an important role in host defense in primates [18]. Although mRNA transcripts for $\theta$-defensins are found in humans, corresponding peptides are not expressed due to a premature stop codon which prevents their translation [19]. It has been proposed that this mutation and the resulting absence of $\theta$-defensins may render humans more susceptible to human immunodeficiency virus (HIV) infection than rhesus macaques [20]. Retrocyclin-1 (RC-100) is a cyclic octadecapeptide humanized $\theta$-defensin, which was initially prepared by solid phase synthesis [19]. It has broad spectrum antimicrobial properties and protects human target cells from HIV-infection in vitro [19]. This protective effect does not involve direct inactivation of the virus but reflects high affinity binding to gp120 and galactosylceramide [21]. An analog of RC-100 containing a single arginine to lysine substitution (RC-101) has greater antimicrobial and anti-HIV effects [22]. Unlike hBD3 and LL-37, retrocyclins are non-hemolytic and noncytotoxic but whether they activate immune cells has not yet been determined [23].

Protegrin-1 (PG-1) is an antimicrobial peptide that was originally isolated from porcine leukocytes [24]. It shares many structural similarities with $\theta$-defensin; it is a cysteine rich octadecapeptide with high arginine content but lacks a cyclic backbone [18]. The antiparallel $\beta$-hairpin conformation of PG-1 is stabilized by two cysteine-cysteine disulfide bonds and contributes substantially to their antimicrobial activity [24-27]. Due to the unique structure and broad-spectrum antimicrobial activities, retrocyclins and PG-1 have immense therapeutic potential against infectious diseases. A major limitation of chemically synthesized peptides is that they are prohibitively expensive $(\sim 600,000-\$ 700,000 /$ gram $)$. In addition, post-synthesis modifications (cyclization, disulfide bonds and folding) are less than adequate for their optimal antimicrobial activity. Most commercial sources of retrocyclin have no antimicrobial activity due to inadequate cyclization. To overcome these limitations, we have expressed RC-101 and PG-1 in transgenic tobacco chloroplasts as GFP-fusion proteins. Both these AMPs are folded properly with suitable posttranslational modifications (cyclization and disulfide bonds) and have potent antimicrobial activity against bacterial and viral pathogens [28].

Currently around 500 - 600 AMP drugs are in clinical trials as a result of their high efficacy, pathogenic specificity and safety shown in in vitro experiments [29].
After establishing the in vitro efficacy of RC-101 against various pathogens, formulated peptide has been shown to be efficacious in several primate and human ex vivo tissue culture models $[22,30]$. RC-101 is also effective in vivo when applied as a topical microbicide on vaginal tissue in a pigtailed macaque model [31]. The preclinical safety shown by this AMP has made it a promising candidate to move ahead with safety trials in humans. In the case of PG-1, Iseganan a synthetic analogue of protegrin has been developed as an oral mouthwash against opportunistic pathogens and has already been tested in several Phase II and Phase III clinical trials [32-34]. Before further trials are carried out, it is important to mechanistically understand the impact of AMPs on non-target cells, especially immunomodulatory cells in addition to their effect on microbes.

Mast cells are multifunctional immune cells found in all mammalian vascularized tissues, most commonly at sites exposed to the external environment, such as the skin, oral mucosa, airway and intestine. Not surprisingly, mast cells play a sentinel role in host defense, orchestrate innate immunity and promote wound healing [35-44]. Mas-related G protein coupled receptor-X2 (MrgX2) was originally identified as a novel $\mathrm{G}$ protein coupled receptor (GPCR) that is expressed in the dorsal root ganglia and participates in the perception of pain [45]. Outside the dorsal root ganglia, the expression of this receptor is restricted to human mast cells and no other immune or structural cells $[46,47]$. We have recently shown that the AMPs such as human $\beta$-defensins and the cathelicidin LL-37 activate human mast cells via MrgX2 to induce $\mathrm{G}$ protein-mediated $\mathrm{Ca}^{2+}$ mobilization and robust mast cell degranulation [6, 7]. Unlike MrgX2, FPRL1 (also known as FPR2), a member of the chemokine GPCRs, is expressed in a variety of cells including mast cells, neutrophils, macrophages and ovarian cancer cells $[8,48$, 49]. Mast cells are the only immune cells that are known to express both MrgX2 and FPRL1. Furthermore, AMPs such as hBD3 and LL-37 activate human mast cells via MrgX2 but pleurocidin does so via FPRL1 [6, 7, 50]. These findings raise the interesting possibility that RC100/RC-101 and PG-1 could activate human mast cells via MrgX2 or FPRL1, thereby contributing to their therapeutic potentials as antimicrobial agents.

With the exception of our recent reports on human defensins, none of the AMPs in clinical development have been investigated for their role in immune modulation via mast cell activation. Here, we report that two AMPs (retrocyclin and protegrin) currently in clinical development activate human mast cells via a mechanism different from human HDPs (independent of FPRL1) but through the same receptor $(\mathrm{MrgX} 2)$. Our studies also demonstrate a dissociation of synthetic RC-100's ability to activate mast cells from its antimicrobial activity and could reflect the peptide's cyclization status. Unlike most GPCRs that are expressed in mast cells, MrgX2 is located 
at both plasma membrane and intracellular sites [6, 47] but the relative contribution of these receptors on mast cell activation is unknown. The availability of chloroplast expressed GFP-tagged PG-1 allowed us to demonstrate that activation of cell surface MrgX2 by this AMP is sufficient to cause mast cell degranulation. Increased understanding of AMPs' mechanism of action, their interaction with non-target cells and low cost production should facilitate further clinical development.

\section{RESULTS}

\section{PG-1 and RC-100 induce degranulation in HMCs but $\mathrm{RC}-100$ does not have antimicrobial activity}

We used laboratory of allergic diseases 2 (LAD2) cells to determine the effects of PG-1 and RC-100 on mast cell signaling and degranulation. We found that PG-1 (2 $\mu \mathrm{g} / \mathrm{ml}$ ) induced significant degranulation and a maximal response of $\sim 80 \%$ was observed at a concentration of 5 $\mu \mathrm{g} / \mathrm{ml}$ (Figure 1A). Because increase in intracellular $\mathrm{Ca}^{2+}$ mobilization provides an important signal for mast cell degranulation, we sought to determine the effect of PG-1 on this response. We found that PG-1 (3 $\mu \mathrm{g} / \mathrm{ml})$, which caused $\sim 60 \%$ mast cell degranulation, was associated with a sustained $\mathrm{Ca}^{2+}$ response (Figure $1 \mathrm{~B}$ ). To determine the relationship between mast cell activation and antimicrobial activity, we tested the effects of different concentrations of PG-1 on bacterial growth. As shown in Figure 1A and $1 \mathrm{C}, \mathrm{PG}-1$ caused mast cell degranulation and inhibited bacterial growth at a similar concentration range $(2-5 \mu \mathrm{g} /$ $\mathrm{ml})$.

$\mathrm{RC}-100$ also induced degranulation and $\mathrm{Ca}^{2+}$ mobilization in human mast cells and it was more potent than PG-1 (Figure 1D and 1E). Thus, while PG-1 (1 $\mu \mathrm{g} /$ $\mathrm{ml}$ ) did not induce mast cells degranulation, RC-100 at this concentration induced a significant response. Despite this difference, both peptides induced a similar maximal response ( $\sim 80 \%$ degranulation) at a concentration of $5 \mu \mathrm{g} /$ $\mathrm{ml}$. Surprisingly, RC-100 did not prevent bacterial growth even at a high concentration $(5 \mu \mathrm{g} / \mathrm{ml})$ (Figure $1 \mathrm{~F})$, which induced substantial mast cell degranulation (Figure 1D).
(A)

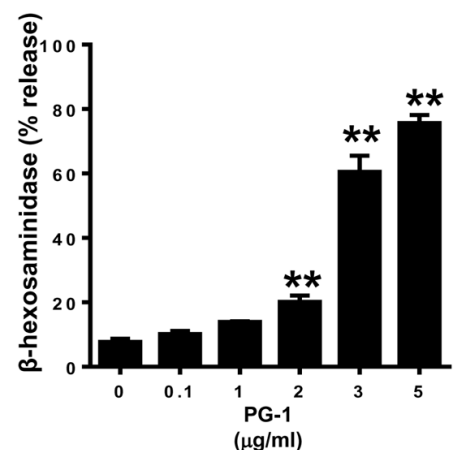

(D)

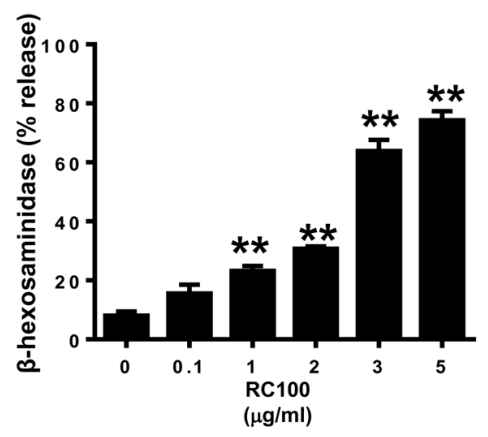

(B)

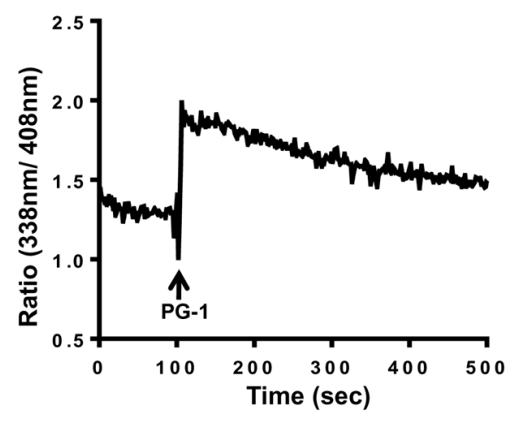

(E)

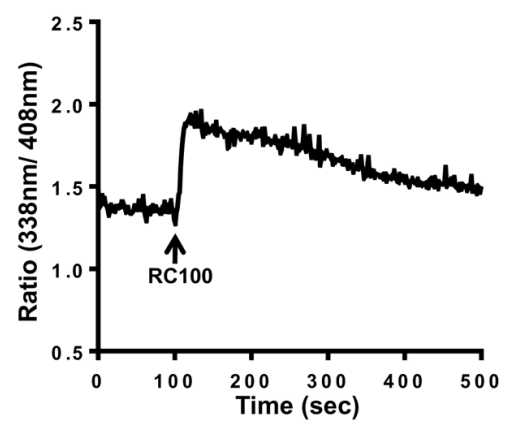

(C)

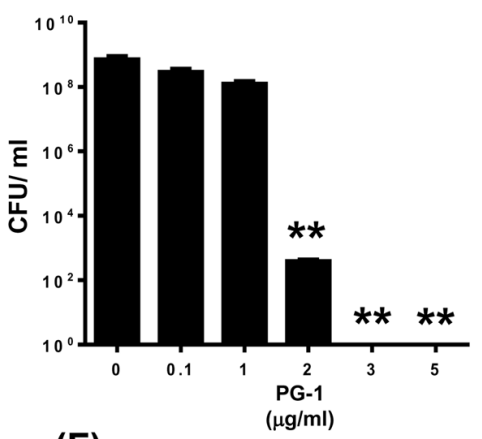

(F)

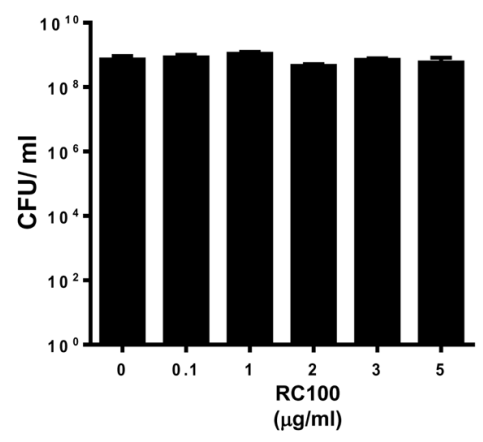

Figure 1: PG-1 and RC-100 induce degranulation and $\mathrm{Ca}^{2+}$ mobilization in LAD2 human mast cells; however have differential antimicrobial activities. LAD2 mast cells were stimulated with different concentrations of A. PG-1 or D. RC-100 and percent degranulation ( $\beta$-hexosaminidase release) was determined. Data are mean \pm SEM of three experiments. LAD2 cells were loaded with Indo-1 AM and $\mathrm{Ca}^{2+}$ mobilization in response B. PG-1 or E. RC-100 (both $3 \mu \mathrm{g} / \mathrm{ml}$ ) was determined. To test the biological activity of the commercial peptides a starting inoculum of $4 \times 10^{5} \mathrm{CFU} / \mathrm{ml}$ of $E$. coli was incubated in the presence of $\mathbf{C}$. PG-1 and $\mathbf{F}$. RC-100 at the indicated concentrations for a period of 8 hours, after which the cultures were plated on LB Agar and incubated overnight. The colony forming units were counted the next day to identify the survival rate of $E$. coli. Data shown are representative of 3 similar experiments. Statistical significance was determined by two-way ANOVA with Bonferroni's post test. ** indicates $p<0.001$. 
Roles of G proteins on PG-1 and RC-100-induced $\mathrm{Ca}^{2+}$ mobilization and degranulation in human mast cells

Next, we sought to determine the involvement of G proteins on mast cell responses to PG-1 and RC-100. Pertussis toxin (PTx), an inhibitor of Gai-family of G protein, is known to block the complement component C3a-induced $\mathrm{Ca}^{2+}$ mobilization and degranulation in human mast cells [51, 52]. While PTx completely blocked $\mathrm{C} 3 a$-induced $\mathrm{Ca}^{2+}$ mobilization it had little or no effect on the responses elicited by either PG-1 or RC-100 (Figure 2A, 2B, 2D and 2E). Notably, treatment of cells with PTx almost completely blocked degranulation induced by PG-1 and RC-100 (Figure 2C and 2F). These findings demonstrate that PG-1 and RC-100 cause degranulation in human mast cells via the interaction of a Gai-independent $\mathrm{Ca}^{2+}$ influx and an unknown Gai-dependent signaling pathway.

\section{PG-1 and RC-100 mediated degranulation in} HMCs does not involve FPRL1

The cathelicidin antimicrobial peptide LL-37 activates human neutrophils and monocytes via the utilization of FPRL1 [8]. Human mast cells also express FPRL1 and the cationic AMP pleurocidin induces mast cell via this receptor [50]. Furthermore, a selective FPRL1 antagonist peptide, WRW4 blocks pleurocidininduced mast cell degranulation [50]. To determine the possible role of FPRL1 on PG-1 and RC-100-induced responses in HMCs, we utilized WRW4. We found that pretreatment of cells with WRW4 had no effect on PG-1 and $\mathrm{RC}-100$ induced $\mathrm{Ca}^{2+}$ mobilization (Figure 3A-3D) or degranulation (Figure 3E). These findings suggest that FPRL1 does not participate in RC-100 or PG-induced mast cell responses.
(A) Control

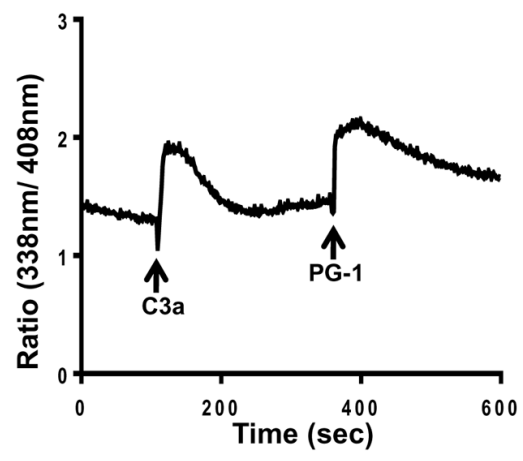

(D) Control

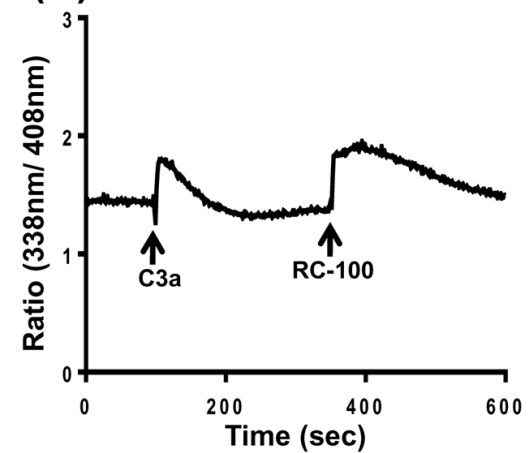

(B) PTx

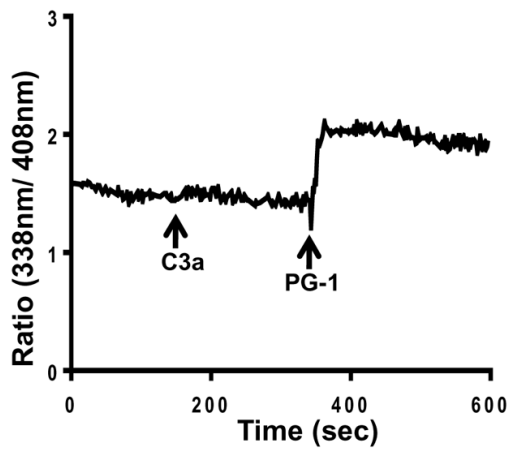

(E) PTx

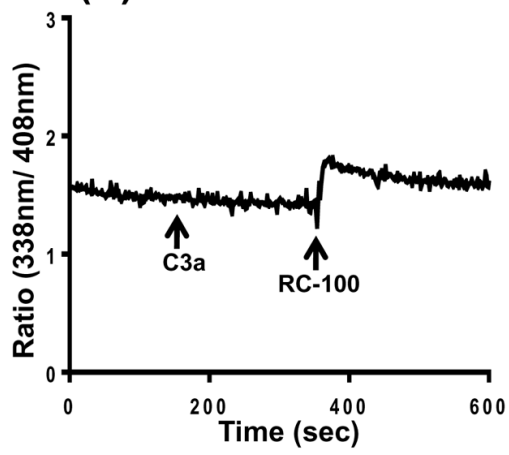

(C)

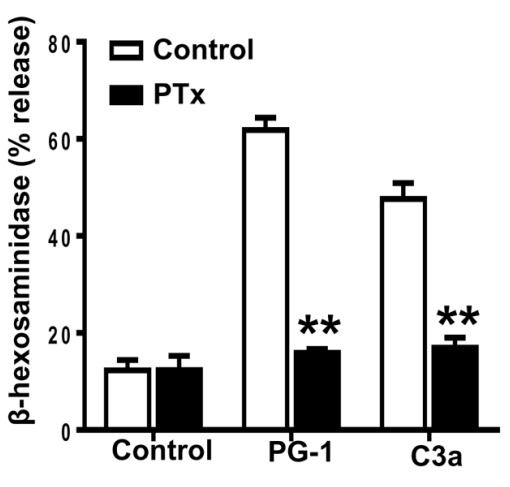

(F)

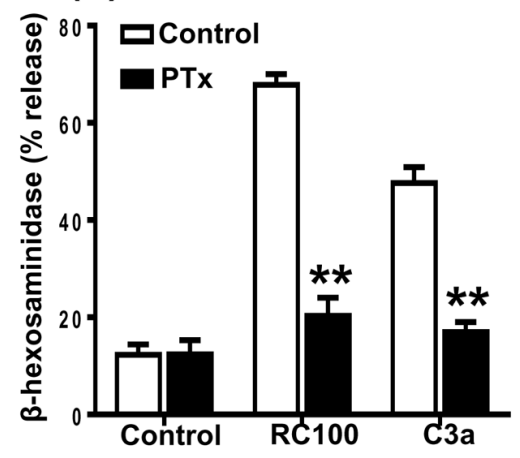

Figure 2: Effects of Pertussis toxin on C3a, PG-1 and RC-100-induced $\mathrm{Ca}^{2+}$ mobilization and degranulation in human mast cells. A., D. Indo-1 loaded LAD2 cells were exposed to C3a (1 nM), followed by PG-1 (3 $\mu \mathrm{g} / \mathrm{ml})$ or RC-100 (3 $\mu \mathrm{g} / \mathrm{ml})$ and intracellular $\mathrm{Ca}^{2+}$ mobilization was determined. B., E. Cells were treated with pertussis toxin (PTx; $\left.100 \mathrm{ng} / \mathrm{ml}, 16 \mathrm{~h}\right)$ and effects of C3a, PG-1 or RC-100 on $\mathrm{Ca}^{2+}$ mobilization was determined. C., F. Cells were exposed to Pertussis toxin (PTx; 100 ng/ml, 16h) and C3a, PG-1 and RC-100-induced degranulation was determined. Data are mean \pm SEM of three experiments. Statistical significance was determined by two-way ANOVA with Bonferroni's post test. and ** indicates $p<0.001$. 
PG-1 and RC-100 activate human mast cells via MrgX2

Considering the recent demonstration that $\mathrm{MrgX} 2$ acts as the receptor for a range of cationic peptides including AMPs $[6,7,46,53]$, we hypothesized that PG-1 and RC-100 could activate HMCs via this receptor. RBL$2 \mathrm{H} 3$ cell is a rat basophilic leukemia cell line that has been extensively used to study the role of IgE receptor (FceRI) and GPCR signaling in mast cells $[51,54,55]$. We have recently shown that RBL-2H3 cells are unresponsive to human AMPs unless the cells are transfected with cDNA encoding $\mathrm{MrgX} 2$ [56]. To determine the role of $\mathrm{MrgX} 2$ on PG-1 and RC-100-induced degranulation, we utilized RBL-2H3 cells stably expressing human MrgX2. In this system, PG-1 and RC-100 induced substantial mast cell degranulation (Figure 4A and 4B). Taken together, these data demonstrate that PG-1, RC-100 activate mast cells via $\operatorname{MrgX} 2$.

\section{Expression and purification of GFP-tagged RC- 101 and PG-1 from transgenic plants}

To determine the expression levels of GFP-RC101 and GFP-PG1 in transgenic plants, plant extracts were quantified by western blotting using anti-GFP antibody (Figure 5A). Expression level of GFP-RC101 was between $20-34 \%$ and GFP-PG1 was $4-8 \%$ of total leaf protein. One gram of fresh leaf yielded about $100 \mu \mathrm{g}$ of GFP protein on an average with an overall recovery of $20 \%$ and $95 \%$ purity. Figure 5B shows the purified GFP-RC101 obtained after dialysis, lyophilization and reconstitution in a small volume of phosphate-buffered saline (PBS) and quantified by immunoblotting against GFP. GFP-RC101 $(29 \mathrm{kDa})$ purified protein has a slightly higher molecular weight than GFP standard (27 kDa) due to RC101 fusion $(1.9 \mathrm{kDa})$. The purity of such preparations was about $90 \%$ when evaluated through immunoblot analysis. To evaluate purity and functionality of GFP-RC101, the purified proteins were run under non-denaturing conditions in a native PAGE. Figure 5C shows purified GFP-RC101 exhibiting increasing fluorescence intensity corresponding to the amount of total protein loaded, confirming GFP
(A) Control

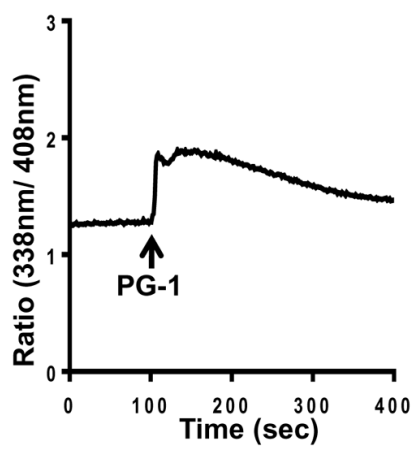

(C) Control

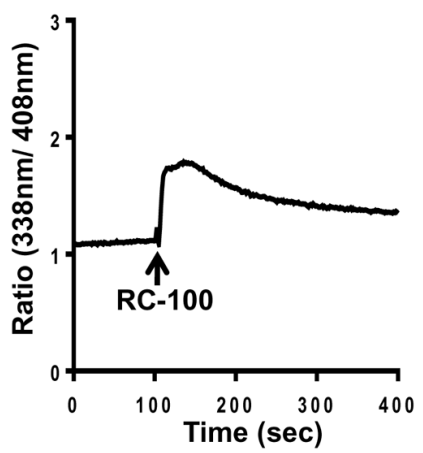

(B) WRW4

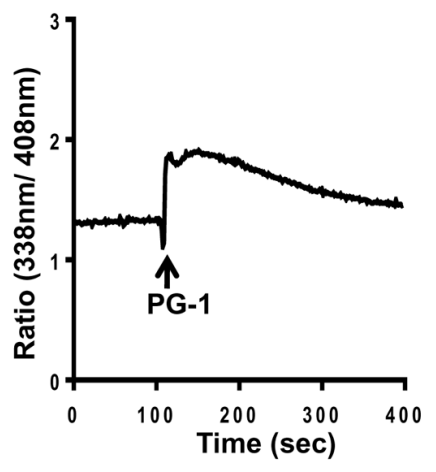

(D) WRW4

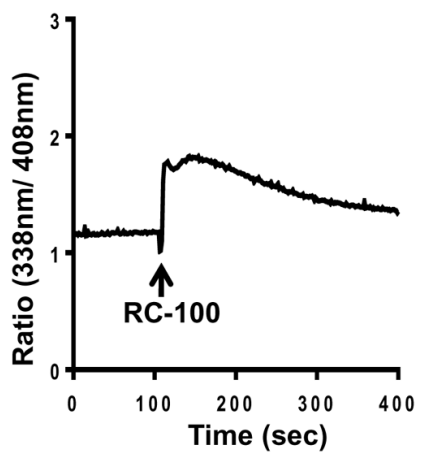

(E)

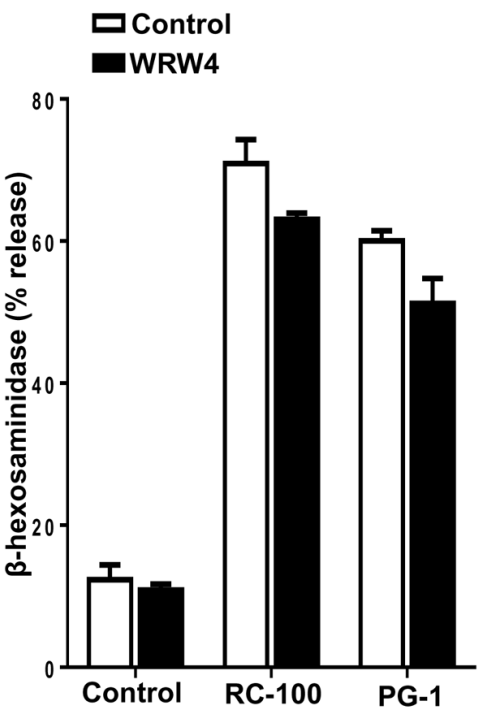

Figure 3: PG-1 and RC-100 induced $\mathrm{Ca}^{2+}$ mobilization and degranulation are independent of FPRL1. Indo-1 loaded LAD2 cells were preincubated with buffer (Control) or WRW4 $(10 \mu \mathrm{M})$ for $30 \mathrm{~min}$ and $\mathrm{Ca}^{2+}$ mobilization was determined in response to A., B. PG-1 $(3 \mu \mathrm{g} / \mathrm{ml})$ or C., D. RC-100 (3 $\mu \mathrm{g} / \mathrm{ml})$. E. LAD2 cells were pretreated with buffer (Control) or WRW4 (10 $\mu$ M) and stimulated with $3 \mu \mathrm{g} / \mathrm{ml}$ concentration of PG-1 and RC-100 and percent degranulation was determined. Data are represented as mean $\pm \mathrm{SEM}$ of three experiments. 
functionality. The distinct bands observed under nondenaturing conditions are due multimerization of the GFP-RC101 and differential electrical mobility due to

(A)

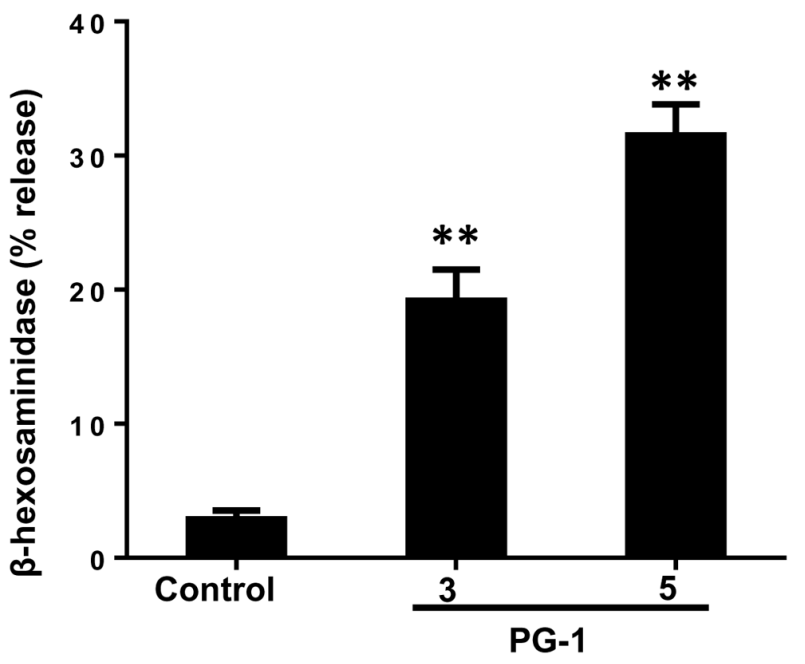

the high positive charge present on RC101 and secondary structures.

\section{(B)}

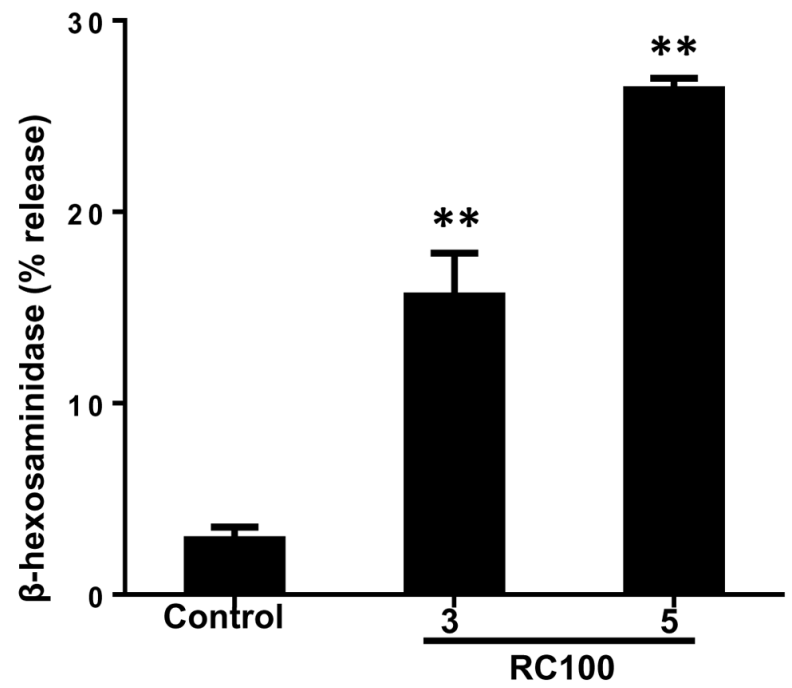

Figure 4: PG-1 and RC-100 induce degranulation in RBL-2H3 cells expressing MrgX2. A., B. RBL-2H3 cells stably expressing MrgX2 were exposed to buffer (Control), PG-1 or RC-100 (3 $\mu \mathrm{g} / \mathrm{ml}, 5 \mu \mathrm{g} / \mathrm{ml})$ for 30 min and $\beta$-hexosaminidase release was measured. Data are represented as mean \pm SEM of three experiments. Statistical significance was determined by one-way ANOVA with Bonferroni's post test. * indicates $p<0.01$ and ** indicates $p<0.001$.

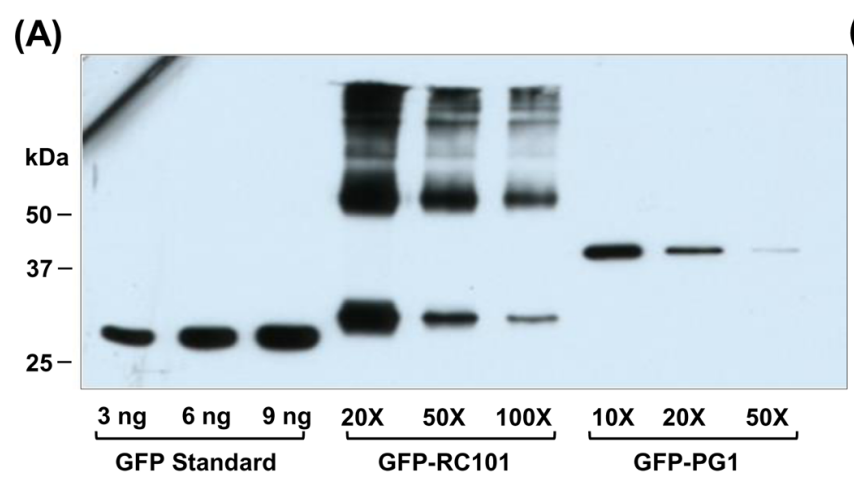

(B)

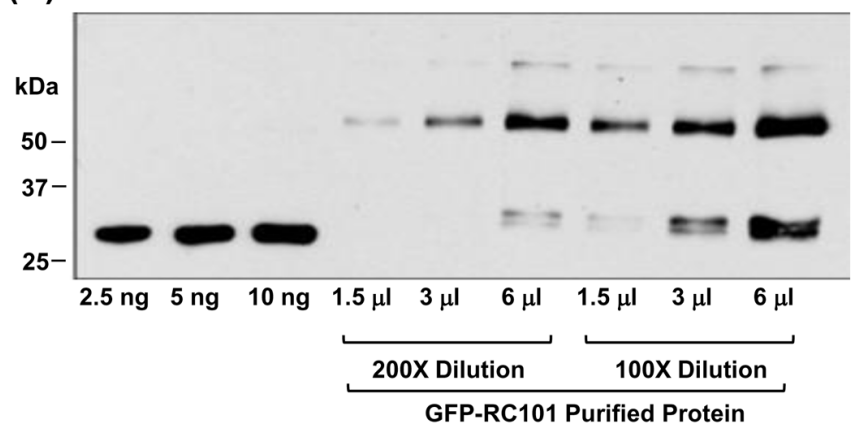

(C)

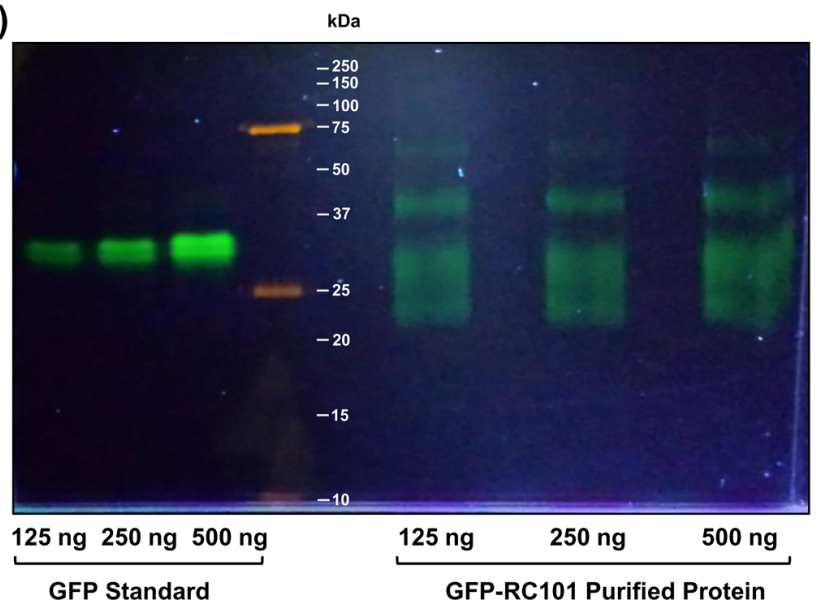

Figure 5: Quantification and evaluation of GFP-RC101 and GFP-PG1 expressed in transgenic plants. A. Western blot analysis of GFP-RC101 and GFP-PG1 protein extracts from the transgenic tobacco leaves. Total Soluble Protein was loaded at indicated dilutions. B. Western blot quantification of GFP- RC101 purified from transgenic tobacco leaves. Purified protein was loaded at the indicated volumes of 100X and 200X dilutions. C. Fluorescence of GFP-RC101 protein is maintained after column purification as seen in non denaturing native PAGE (12\%), observed under UV light. 
(A)

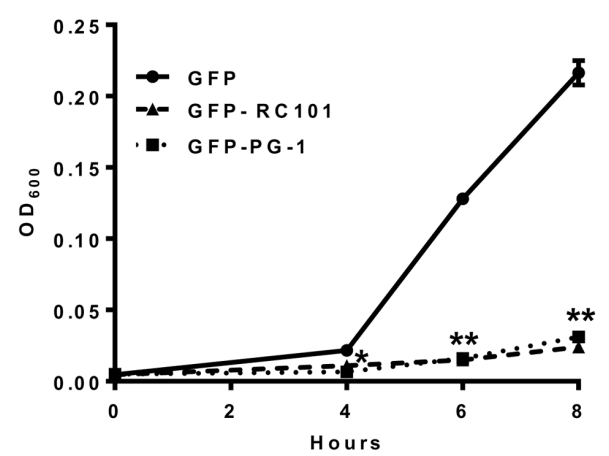

(B)

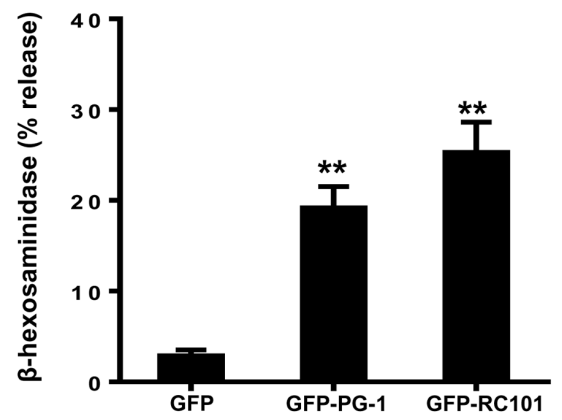

Figure 6: Antimicrobial and immunomodulatory effects of AMPs produced in plants. A. Antimicrobial activity assay of AMPs purified from transplastomic plants against $E$. coli. The inhibitory effect of the AMPs on the growth of $E$. coli (starting inoculum $4 \mathrm{x}$ $10^{5} \mathrm{CFU} / \mathrm{ml}$ ) was measured by monitoring $\mathrm{OD}_{600}$ for $8 \mathrm{~h}$ in the presence of vehicle control (GFP), GFP-RC101 $(0.8 \mu \mathrm{g} / \mathrm{ml})$ or GFP-PG1 (0.5 $\mu \mathrm{g} / \mathrm{ml})$. B. LAD2 cells were exposed to vehicle control (GFP), GFP-RC101 $(1.8 \mu \mathrm{g} / \mathrm{ml})$ or GFP-PG1 $(2.4 \mu \mathrm{g} / \mathrm{ml})$ and percent degranulation ( $\beta$-hexosaminidase release) was determined 30 min after stimulation. Data are represented as mean $\pm \mathrm{SEM}$ of three experiments. Statistical significance was determined by one-way ANOVA with Bonferroni's post test. * indicates $p<0.01$ and ** indicates $p<0.001$.

\section{(A) Mock Transfected}

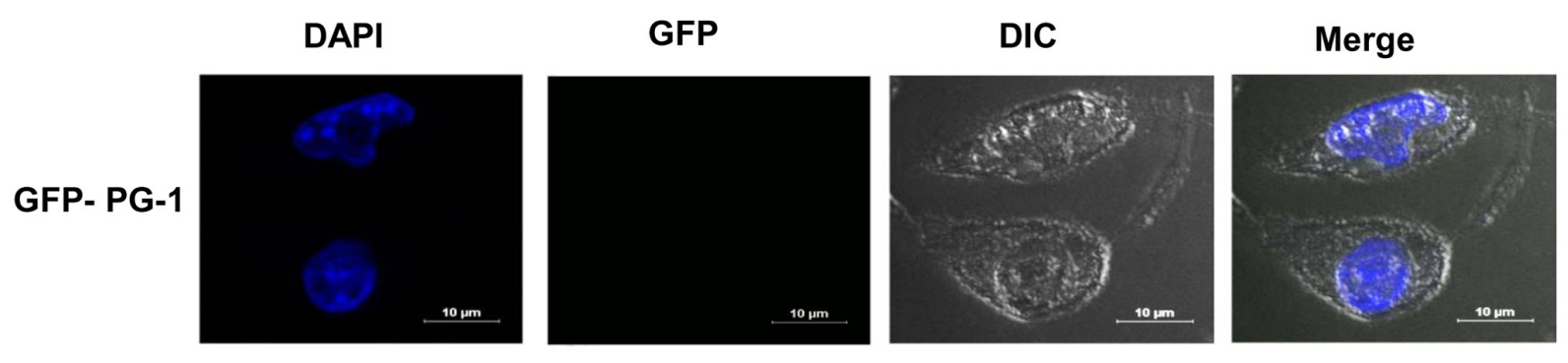

\section{(B) MrgX2 Transfected}

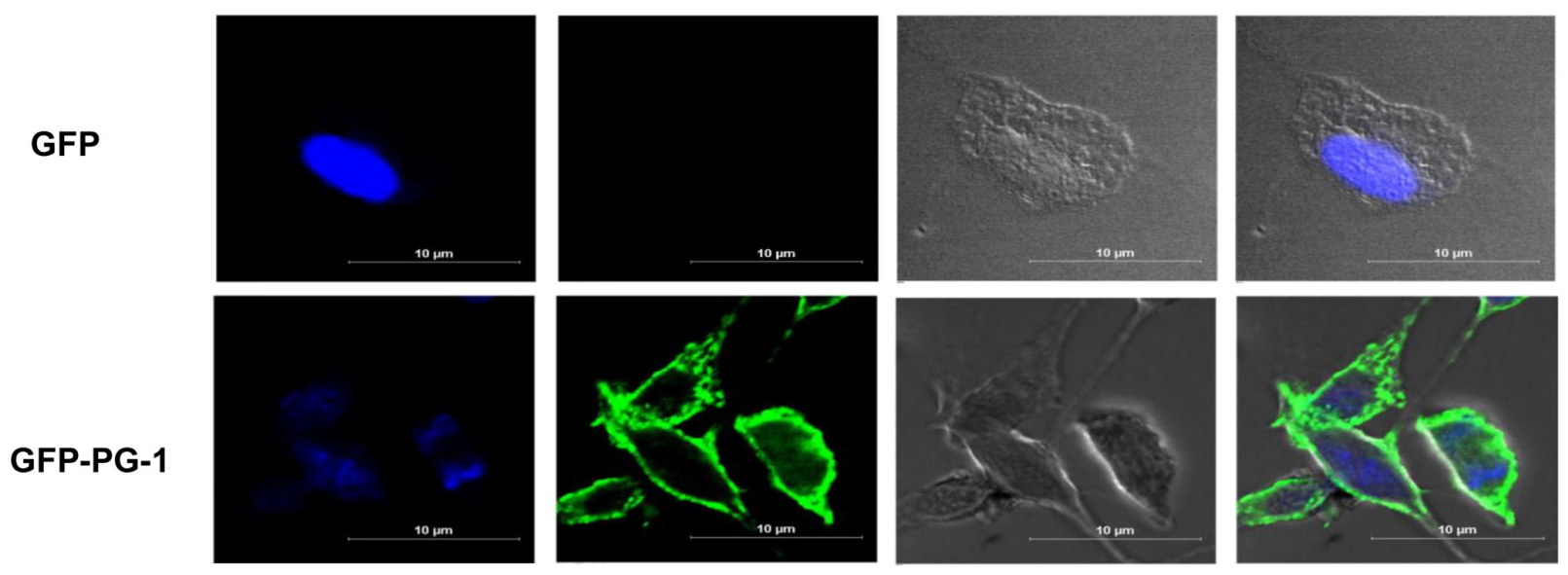

Figure 7: GFP-PG1 associate with the plasma membrane of MrgX2-expressing RBL-2H3 cells A. Mock transfected RBL-2H3 cells were exposed to GFP-PG1 (4 $\mu \mathrm{g} / \mathrm{ml}, 30 \mathrm{~min}$ ) and B. RBL-2H3 cells transfected with MrgX2 were exposed to either GFP or GFP-PG1 (4 $\mu \mathrm{g} / \mathrm{ml}, 30 \mathrm{~min})$. Cells were washed with ice cold PBS, fixed in $4 \%$ paraformaldehyde, nuclei were counter-stained with 4'-6-diamidino-2-phenylindole dihydrochloride (DAPI) and observed using laser scanning confocal microscope (Nikon A1R) with a 60x water objective and 5.6X digital zoom. Images were analyzed using Nikons Elements 4.1 software and representative images from 25 stored images for each condition are shown. 


\section{GFP-RC101 and GFP-PG1 isolated from plant chloroplast display antimicrobial activity and cause mast cell degranulation via MrgX2}

To determine antimicrobial activity of chloroplastderived GFP-RC101 and GFP-PG1, we tested their effects on growth of $E$. coli. As shown in Figure 6A, both peptides completely inhibited growth of $E$. coli. To determine their effects on mast cell degranulation, we incubated LAD2 mast cells with GFP-RC101 $(1.8 \mu \mathrm{g} / \mathrm{ml})$ and GFP-PG1 $(2.4 \mu \mathrm{g} / \mathrm{ml})$. We found that GFP-PG1 and GFP-RC101 cause significant degranulation of human mast cells (Figure 6B) and such responses were equivalent to those elicited by chemically synthesized commercial peptides (Figure 1A and 1D).

An important property of $\mathrm{MrgX} 2$ that distinguishes it from other GPCRs in mast cells is that this receptor is located at both plasma membrane and intracellular sites [6, 47]. This raises an interesting possibility that $\mathrm{PG}-1$ or RC101 could activate mast cells via their interaction with cell surface or intracellular receptors. To test this possibility, we exposed mock or MrgX2-transfected RBL-2H3 cells to GFP alone or GFP-PG1 for $30 \mathrm{~min}$ and observed GFP fluorescence in mast cells by confocal microscopy. As shown in Figure 7A, GFP-PG1 did not associate with mock-transfected RBL-2H3 cells. In contrast, GFP-PG1 was associated with the plasma membrane of MrgX2expressing cells but not GFP alone without PG1 fusion (Figure 7B). These findings suggest that GFP-PG1 induces mast cell degranulation via the activation of $\mathrm{MrgX} 2$ receptors that are present on the cell surface.

\section{DISCUSSION}

Retrocyclins and protegrins are cyclic or acyclic peptides with potent antimicrobial activities against a broad spectrum of microorganisms, including bacteria, fungi, yeast. They also bind to glycoprotein 120 to prevent HIV entry. These peptides therefore have potential for use as anti-microbial and anti-HIV agents. Many AMPs not only display antimicrobial activity but they also have immunomodulatory and wound healing properties that can be harnessed for their therapeutic activity. However, to the best of our knowledge, the effects of retrocyclins and protegrins on the activation of immune cells such as mast cells have never been tested.

An important limitation of studies with these peptides is the tremendously high cost of their chemical synthesis $(\$ 600,000$ - $\$ 700,000 /$ gram $)$. In addition, postsynthesis modifications (cyclization, disulfide bonds and folding) are less than adequate for optimal antimicrobial activity. Thus, most commercial source of retrocyclin has no or negligible antimicrobial activity due to inadequate cyclization or other post-translational modifications. Synthesis of recombinant AMPs in microbial systems is challenging because of their antimicrobial activity. Therefore, in this study, we compared both chemically synthesized and recombinant GFP-tagged peptides expressed in chloroplasts and evaluated their antimicrobial and immunomodulatory properties. Chloroplasts are prokaryotic compartments within eukaryotic cells with exceptional ability to synthesize foreign proteins from different kingdoms including bacterial [57] viral [58] fungal [59], animal [60] and human genes [61-65]. Because of expression of $>10,000$ copies of transgenes in each plant cell, foreign proteins are expressed at very high levels (up to $70 \%$ of total leaf protein). Expressed recombinant proteins can be indefinitely stored at ambient temperature in lyophilized cells maintaining their efficacy and functionality $[66,67]$, thereby eliminating expensive cold storage/transportation and short shelf life. These are highly desired features for affordable production and delivery of human therapeutic proteins in the clinic.

Most importantly, chloroplasts perform all posttranslational modifications required for fully functional antimicrobial peptides including folding, stabilization with disulfide bond and cyclization. Several studies have shown that human blood proteins (like insulin, interferon, etc), when expressed in chloroplasts are properly folded with disulfide bonds and are fully functional upon oral or injectable delivery $[68,69]$. Chloroplasts also assemble complex multimeric structures (like cholera toxin B) with disulfide bonds that bind to epithelial cell receptors like GM1 (General Monosialotetrahexosylganglioside) [60, $61,64,70-73]$. Assembly of virus-like particles that are required for stability and efficacy of vaccine antigens has been observed in chloroplasts [74, 75]. Protein disulfide isomerase/thioredoxin expression has been shown to enhance folding and assembly of human serum albumin within chloroplasts, a complex protein requiring 17 disulfide bonds [76]. Cyclization with disulfide bonds is required for antimicrobial activity of retrocyclin and chloroplasts synthesize and fold such cyclic proteins [28]. Functional evaluation of both protegrin and retrocyclin synthesized in chloroplasts, in this study, again confirms proper folding and formation of disulfide bonds.

Human mast cells express FPRL1 and MrgX2 and these GPCRs are activated by different AMPs [6, $7,50]$. We found that a potent and selective inhibitor of FPRL1 had no effect on RC-100 or PG-1-induced $\mathrm{Ca}^{2+}$ mobilization and degranulation. Furthermore, expression of $\mathrm{MrgX} 2$ in a rodent mast cell line RBL-2H3 cells, which do not endogenously express this receptor, rendered these cells responsive to both RC-100 and PG-1 for degranulation. These findings demonstrate that RC-100 and $\mathrm{PG}-1$ bind to $\mathrm{MrgX} 2$ receptor to induce signaling and degranulation in human mast cells. It is noteworthy that in unstimulated mast cells, $\mathrm{MrgX} 2$ is located at both plasma membrane and intracellular sites [6, 47]. There is now growing body of evidence for the role of both plasma membrane and intracellular GPCRs for sustained signaling 
and effector function [77]. Substance P, which couples to $\operatorname{MrgX} 2$, has been shown to activate intracellular $\mathrm{G}$ proteins to induce mast cell degranulation $[46,78]$. This raises the interesting possibility that AMPs used in this study could induce mast cell degranulation via the activation of intracellular MrgX2. The availability of GFP-PG1 allowed us to test this possibility. The findings that GFP-PG1 interacted with RBL-2H3 transiently expressing MrgX2 but not mock transfected cells clearly demonstrated a specific ligand-receptor interaction. We found that the interaction of GFP-PG1 with MrgX2-expressing RBL$2 \mathrm{H} 3$ cells was localized to the plasma membrane and no green fluorescence was detected at intracellular sites even after prolonged incubation. This finding demonstrates that GFP-PG1 interacts with cell surface MrgX2 on mast cells to induce signaling and degranulation.

One important finding of the present study is that while the synthetic RC-100 activated mast cells via MrgX2, it had no detectable antimicrobial activity. The data sheet from the manufacturer indicated that the peptide is $>95 \%$ pure and has the appropriate molecular mass but did not provide evidence for antimicrobial activity. It has previously been shown that while structures and stabilities of retrocyclins depend on the number and position of the disulfide bonds, their antimicrobial and membrane binding properties depend on the presence of cyclic backbone [21]. Our previous studies have shown that both linear and cyclic cationic peptides including substance $\mathrm{P}, \mathrm{hBD} 3$ and LL-37 activate human mast cells via $\operatorname{MrgX} 2[6,7$, 56]. Thus, it is likely that the cationic residues on AMPs such as hBD3, LL-37, retrocyclins and protegrins interact with negatively charged residues on MrgX2 to induce mast cell activation but their ability to cause microbial killing requires additional posttranslational modifications (cyclization, disulfide bonds, folding). These findings suggest that different structural determinants on AMPs dictate their antimicrobial and immunomodulatory properties. Thus, new molecules can be designed in the future to modulate their different functions.

Unlike circulating leukocytes, mast cells are tissue resident cells that are found beneath the epithelium and close to blood vessels. The epithelium expresses pattern recognition receptors (e.g. toll-like receptors), which responds to infectious agents to generate AMPs [79, 80]. These cationic peptides kill microbes by binding to negatively charged residues on their membrane [81]. Mast cell degranulation plays an important role in innate immunity by causing increased vascular permeability and by initiating the recruitment of neutrophil to the sites of infection [36-39, 43, 44]. We have previously shown that hBD3, which is derived from epithelial cells, activates human mast cell via MrgX2 [7]. Furthermore, hBD3 increases vascular permeability in a mast cell-dependent manner [82]. These findings suggest that MrgX2 expressed in mast cells contributes to innate immunity via its effects on vascular permeability and neutrophil recruitment.
In addition to innate immunity, mast cells orchestrate the development of adaptive immunity and play an important role in wound healing [35, 40-42]. Thus, at sites of microbial infection, mediators released from mast cells promote migration of dendritic cells, which are subsequently increased in draining lymph nodes [8385]. Furthermore, mast cell-derived histamine directly modulates dendritic cell activation to enhance antigen presentation to $\mathrm{T}$ cells [86]. Interestingly, compound 48/80, which activates mast cells via MrgX2, has been used as a safe and effective vaccine adjuvant in mice [42, $46,87]$. Wound healing is a dynamic process that involves a number of overlapping phases including inflammation, granulation tissue formation, wound contraction and remodeling. Wound provides an excellent breeding ground for microbes and proper healing is dependent on managing the microbial burden. Interestingly, LL-37 and hBD3, which display antimicrobial activity and cause mast cell degranulation via MrgX2, also promote wound healing $[6,11,12,88]$. It is noteworthy that mast cells are only immune cells that express MrgX2 and the data presented herein demonstrate that retrocyclins and PG-1 activate mast cells via this receptor. These findings suggest that potential therapeutic benefits of retrocyclin/PG-1 and other AMPs in vivo not only reflects their antimicrobial activity but also involves the harnessing of mast cell's immunomodulatory and wound healing properties.

In conclusion, biopharmaceuticals produced in current systems are prohibitively expensive and are not affordable for a large majority of the global population. Chemically synthesized AMPs used in this study cost $\$ 600,000$ - \$700,000 per gram and their post-synthesis modifications (cyclization, disulfide bonds, folding) are inadequate for optimal antimicrobial activity (retrocyclin 100 has no detectable antimicrobial activity). Therefore, in this report we synthesized fully functional AMPs in plant chloroplasts, making them affordable for the large global population who often face outbreak of infectious diseases. Enhancing our understanding of mechanistic aspects of AMPs is important for clinical development. With the exception of our recent reports on human HDPs, none of the AMPs in clinical development have been investigated for their role in immune modulation via mast cell activation. Here, we report the novel finding that two AMPs (retrocyclin and protegrin) currently in clinical development as antimicrobial agents activate human mast cells via MrgX2. Using AMPs with GFP fusion expressed in plant chloroplasts we demonstrate that activation of cell surface receptor is sufficient to cause mast cell degranulation without involvement of the intracellular receptor. Increased understanding of AMPs mechanism of action, their interaction with non-target cells and low cost production should facilitate further clinical development. 


\section{MATERIALS AND METHODS}

All cell culture reagents and pertussis toxin were purchased from Invitrogen (Gaithersburg, MD). Amaxa transfection kit (Kit V) (Lonza, Gaithersburg, MD), recombinant human cytokines (Peprotech, Rocky Hill, NJ), C3a (Complement Technology, Tyler, TX), RC100 (VWR Bachem, Louisville, KY) and Protegrin 1 (Anaspec, Freemont, CA) were purchased from the sources indicated.

\section{Culture of mast cell lines}

LAD2 human mast cells were maintained in complete StemPro-34 medium supplemented with $100 \mathrm{ng} /$ $\mathrm{ml} \mathrm{hSCF}$ [89]. Rat basophilic leukemia (RBL-2H3) cells were maintained as monolayer cultures in Dulbecco's modified Eagle's medium (DMEM) supplemented with $10 \%$ FBS, L-glutamine $(2 \mathrm{mM})$, penicillin $(100 \mathrm{IU} / \mathrm{ml})$ and streptomycin $(100 \mathrm{mg} / \mathrm{ml})$ [90].

\section{Transfection of RBL-2H3}

RBL-2H3 cells were transfected with plasmids encoding hemeagglutinin (HA)-tagged MrgX2 using the Amaxa nucleofector device and Amaxa kit $\mathrm{V}$ according to the manufacturer's protocol. Following transfection, cells were cultured in the presence of G-418 $(1 \mathrm{mg} / \mathrm{ml})$ and cells expressing equivalent receptors were sorted using an anti-HA specific antibody 12CA5/FITC-conjugated anti-mouse-IgG and subsequently used for studies on degranulation and confocal microscopy.

\section{Calcium mobilization}

$\mathrm{Ca}^{2+}$ mobilization was determined as described previously [90]. Briefly, LAD2 cells $\left(0.2 \times 10^{6}\right)$ were loaded with indo-1 AM $(1 \mu \mathrm{M})$ for $30 \mathrm{~min}$ at room temperature. Cells were washed and resuspended in 1.5 $\mathrm{ml}$ of HEPES-buffered saline. $\mathrm{Ca}^{2+}$ mobilization was measured in a Hitachi F-2500 spectrophotometer with an excitation wavelength of $355 \mathrm{~nm}$ and an emission wavelength of $410 \mathrm{~nm}$.

\section{Degranulation}

LAD2 cells $\left(5 \times 10^{3}\right)$ and RBL-2H3 cells $\left(5 \times 10^{4}\right)$ were seeded into 96-well plates in a total volume of $50 \mu \mathrm{l}$ HEPES buffer containing $0.1 \%$ BSA and exposed to the indicated peptides. In some assays cells were pretreated with pertussis toxin (PTx, $100 \mathrm{ng} / \mathrm{ml}, 16 \mathrm{~h}$ ). For total $\beta$-hexosaminidase release, unstimulated cells were lysed in $50 \mu \mathrm{l}$ of $0.1 \%$ Triton X-100. Aliquots $(20 \mu \mathrm{l})$ of supernatant or cell lysate were incubated with $20 \mu \mathrm{l}$ of
$1 \mathrm{mM}$ p-nitrophenyl-N-acetyl- $\beta$-D-glucosamine for 1.5 $\mathrm{h}$ at $37^{\circ} \mathrm{C}$. Reaction was stopped by adding $250 \mu \mathrm{l}$ of a $0.1 \mathrm{M} \mathrm{Na}_{2} \mathrm{CO}_{3} / 0.1 \mathrm{M} \mathrm{NaHCO}_{3}$ buffer and absorbance was measured at $405 \mathrm{~nm}$ [90].

\section{Biomass production and immunoblot analysis of AMPs from transgenic plants}

Seeds from transplastomic plants expressing GFP-RC101 and GFP-PG1 [28] were germinated on Murashige and Skoog medium containing $500 \mathrm{mg} / \mathrm{l}$ spectinomycin. After confirmation of GFP fluorescence, transgenic plants expressing AMPs were transferred to pots in the greenhouse for growth under controlled light, temperature and moisture. Because the psbA sequence used for the transgene expression is regulated by light mature leaves were harvested at 6 PM for maximizing protein accumulation. To determine GFP protein expression levels Bradford assay was performed on plant extracts and purified proteins to find the total soluble protein (TSP) concentration. Based on this, appropriate dilutions were made and mixed with $5 \mathrm{X}$ sample buffer. The GFP standard and samples were boiled for 3 minutes and loaded onto a $1.0 \mathrm{~mm}$ thick 12\% SDS-PAGE gel for electrophoresis. The separated proteins were then transferred onto nitrocellulose membrane at $85 \mathrm{~V}$ for 45 min. The nitrocellulose membrane was then blocked with PTM (1X PBS, 0.05\% Tween-20, 3\% Milk) for $1 \mathrm{~h}$ at room temperature. Mouse anti-GFP primary antibody (EMD Millipore, cat\# MAB 3836, 1:3,000) was added in PTM and incubated overnight at $4{ }^{\circ} \mathrm{C}$. The membrane was washed 3 times with PBS-T (1X PBS, 0.05\% Tween-20), 10 min each time. Goat anti-mouse secondary antibody (Southern Biotech, cat\# 1031-05, 1:4,000) was added in PTM and incubated for $2 \mathrm{~h}$ at room temperature. Membrane was developed using SuperSignal West Pico chemiluminescent substrate (Thermo Scientific, cat\# 34079).

\section{Purification of AMPs from plants}

The GFP-PG1, GFP-RC101 and control GFP peptides were purified as described previously [28]. One gram of finely ground frozen leaf material was suspended in $5 \mathrm{ml}$ of protein extraction buffer $(100 \mathrm{mM} \mathrm{NaCl}, 10$ mM EDTA, $200 \mathrm{mM}$ Tris $\mathrm{HCl} \mathrm{pH} 8,0.2 \%$ [v/v] Triton $\mathrm{X}-100,400 \mathrm{mM}$ sucrose, and $2 \mathrm{mM}$ phenylmethylsulfonyl fluoride, $1 \mathrm{X}$ solution of Pierce protease inhibitor cocktail). Vortexed samples were sonicated and centrifuged at $2500 \mathrm{x}$ g for $5 \mathrm{~min}$. The lysate was then subjected to the organic extraction protocol described by Skosyrev et al [91]. Saturated ammonium sulfate solution was added to the cleared lysate so that the final lysate contained $70 \%$ ammonium sulfate $[\mathrm{v} / \mathrm{v}]$. The precipitated proteins were then extracted into $100 \%$ ethanol by adding $1 / 4^{\text {th }}$ and $1 / 16^{\text {th }}$ 
of the volume of the lysate/ammonium sulfate mixture (aqueous phase) followed by shaking for $2 \mathrm{~min}$ and centrifugation at $2500 \mathrm{x}$ g for $5 \mathrm{~min}$. The ethanol extracts were pooled and to $1 / 3^{\text {rd }}$ volume of this ethanol phase $5 \mathrm{M}$ $\mathrm{NaCl}$ was added to make a final concentration of $1.6 \mathrm{M}$. The aqueous phase was collected and salt was removed using a desalting column (Thermo Scientific, Zeba spin column, $7 \mathrm{kDa}$ MWCO). The desalted aqueous phase was loaded onto the Butyl-Toyopearl Hydrophobic Interaction Column (TOSOH Butyl-650S resin, Grade S resin, particle size $65 \mu \mathrm{m}$, Column Volume $48 \mathrm{ml}$ ) pre-equilibrated with $20 \%$ ammonium sulfate in $10 \mathrm{mM}$ Tris- $\mathrm{HCl}, 10 \mathrm{mM}$ EDTA pH 7.8. Subsequently, the column was washed with 3 column volume (CV) of the equilibration buffer and $2 \mathrm{CV}$ with $10 \%$ step wise reduction in ammonium sulfate. Proteins were eluted with salt free elution buffer containing $10 \mathrm{mM}$ Tris-HCl, $10 \mathrm{mM}$ EDTA pH 7.8. The proteins were then dialyzed three times in dialysis buffer containing $1 \mathrm{mM} \mathrm{NaCl}, 0.1 \mathrm{mM}$ Tris- $\mathrm{HCl}$, and $10 \mu \mathrm{M}$ EDTA, pH 8.0. Dialyzed proteins were shell frozen in a freezing bath and lyophilized. The purified proteins were then reconstituted in a small volume of reconstitution buffer (PBS, 10\% glycerol).

\section{Fluorescence gel and fluorescence intensity readings}

Total soluble protein (TSP) concentration was determined by the Bradford assay, and different quantities of protein were loaded with non-denaturing sample buffer (50 mM Tris- $\mathrm{HCl}$, pH 6.8, 2\% SDS, 0.04\% Bromophenol blue, $10 \%$ glycerol) into a $12 \%$ native polyacrylamide gel. After electrophoresis, gels were observed under UV light for GFP fluorescence. Images were taken and analyzed with Image J software. For fluorescence intensity calculations, the Gemini EM microplate reader was used and calculations were done with the Softmax Pro software (Molecular Devices). Standard GFP (Millipore, cat\# 14-392) was used to calculate GFP concentrations in samples based on the fluorescence intensity. Samples and GFP standards (standard curve range from $31.25 \mathrm{ng}$ to $500 \mathrm{ng}$ ) were dissolved in $200 \mu \mathrm{l}$ of $10 \mathrm{mM}$ Tris- $\mathrm{HCl}$ pH 8.0 and fluorescence intensities were measured by exciting the samples at $400 \mathrm{~nm}$ and measuring emission at $510 \mathrm{~nm}$ using a 96-well optical bottom plate. For Commassie staining gels were soaked in fixing solution (40\% ethanol, 10\% acetic acid in Milli Q water) for 20 $\mathrm{min}$ at room temperature on a shaker. Subsequently, the gel was stained overnight in colloidal Coomassie G-250 stain (35\% methanol, 2.5\% phosphoric acid and 10\% ammonium sulfate in Milli Q water) and destained first by rinsing with water three times followed $10 \%$ acetic acid.

\section{Antimicrobial assay}

Antimicrobial assay was adapted from the microbroth dilution assay described by Steinberg and Lehrer [92]. An overnight culture of $E$ coli grown in tryptic soy broth (TSB) was diluted to 1:20 in the same media and $\mathrm{OD}_{600}$ was measured using the Nanodrop 2000C spectrophotometer. From the measured OD value the bacterial concentration in terms of colony forming units $(\mathrm{CFU}) / \mathrm{ml}$ was calculated based on the formula provided below.

A bacterial density of $4 \times 10^{5} \mathrm{CFU} / \mathrm{ml}$ was used as the starting inoculum. Bacterial suspension $(250 \mu \mathrm{l})$ was grown in the presence of AMPs at the indicated final concentrations on a shaker (VWR Benchtop Shaking Incubator, Model 1570) at $240 \mathrm{RPM}$ and $37^{\circ} \mathrm{C}$. The growth curves of these cultures were followed for $8 \mathrm{~h}$ by measuring $\mathrm{OD}_{600}$ at $2 \mathrm{~h}$ intervals. At the end of $8 \mathrm{~h}$ the cultures were diluted and plated on LB agar to determine CFU the next day.

\section{Confocal microscopy}

Mock and MrgX2-transfected RBL-2H3 cells were grown on coverslips and maintained in fresh complete media. Cells were incubated with control GFP and PG1-GFP $(4 \mu \mathrm{g} / \mathrm{ml})$ for $30 \mathrm{~min}$ in $50 \mu \mathrm{l}$ HEPES buffer containing $0.1 \%$ BSA, washed with ice cold PBS and then fixed in $4 \%$ paraformaldehyde solution. Confocal microscopy was performed on a Nikon A1R laser scanning confocal microscope with a 60x water objective (NA 1.2), using a fluorescein isothiocyanate filter with the emission wavelength of $488 \mathrm{~nm}$. Images were analyzed using Nikons Elements 4.1 software.

\section{ACKNOWLEDGMENTS}

We thank Drs. Arnold Kirshenbaum and Dean Metcalfe (NIAID/NIH) for providing LAD2 mast cells and the FACS core facilities of Penn Dental Medicine (PDM) for acquisition, analysis and cell sorting. We also thank the live cell confocal imaging core at PDM for studies with GFP-fusion proteins.

\section{FUNDING}

This work was supported by NIH grants AI108585 to HA and R01-HL107904, R01-HL109442 to HD. It was also supported by K99-HL121073 to HS.

\section{CONFLICTS OF INTEREST}

All authors have no conflict of interest except HD who has several awarded US and global patents 
on expression of human therapeutic proteins including antimicrobial peptides in plant chloroplasts.

\section{REFERENCES}

1. Laxminarayan R, Duse A, Wattal C, Zaidi AK, Wertheim HF, Sumpradit N, Vlieghe E, Hara GL, Gould IM, Goossens H, Greko C, So AD, Bigdeli M, Tomson G, Woodhouse W, Ombaka E, et al. Antibiotic resistance-the need for global solutions. The Lancet Infectious diseases. 2013; 13:10571098.

2. Boldenow E, Jones S, Lieberman RW, Chames MC, Aronoff DM, Xi C and Loch-Caruso R. Antimicrobial peptide response to group B Streptococcus in human extraplacental membranes in culture. Placenta. 2013; 34:480-485.

3. Zaga-Clavellina V, Ruiz M, Flores-Espinosa P, VegaSanchez R, Flores-Pliego A, Estrada-Gutierrez G, SosaGonzalez I, Morales-Mendez I and Osorio-Caballero M. Tissue-specific human beta-defensins (HBD)-1, HBD-2 and HBD-3 secretion profile from human amniochorionic membranes stimulated with Candida albicans in a twocompartment tissue culture system. Reproductive biology and endocrinology: RB\&E. 2012; 10:70.

4. van der Does AM, Bergman P, Agerberth B and Lindbom L. Induction of the human cathelicidin LL-37 as a novel treatment against bacterial infections. J Leukoc Biol. 2012; 92:735-742.

5. Yang D, Chertov O, Bykovskaia SN, Chen Q, Buffo MJ, Shogan J, Anderson M, Schroder JM, Wang JM, Howard $\mathrm{OM}$ and Oppenheim JJ. Beta-defensins: linking innate and adaptive immunity through dendritic and T cell CCR6. Science. 1999; 286:525-528.

6. Subramanian H, Gupta K, Guo Q, Price R and Ali H. Mas-related gene X2 (MrgX2) is a novel G proteincoupled receptor for the antimicrobial peptide LL-37 in human mast cells: resistance to receptor phosphorylation, desensitization, and internalization. J Biol Chem. 2011; 286:44739-44749.

7. Subramanian H, Gupta K, Lee D, Bayir AK, Ahn H and Ali $H$. beta-Defensins activate human mast cells via Masrelated gene X2. J Immunol. 2013; 191:345-352.

8. De Y, Chen Q, Schmidt AP, Anderson GM, Wang JM, Wooters J, Oppenheim JJ and Chertov O. LL-37, the neutrophil granule- and epithelial cell-derived cathelicidin, utilizes formyl peptide receptor-like 1 (FPRL1) as a receptor to chemoattract human peripheral blood neutrophils, monocytes, and T cells. J Exp Med. 2000; 192:1069-1074.

9. Rohrl J, Yang D, Oppenheim JJ and Hehlgans T. Human beta-defensin 2 and 3 and their mouse orthologs induce chemotaxis through interaction with CCR2. J Immunol. 2010; 184:6688-6694.

10. Koczulla R, von Degenfeld G, Kupatt C, Krotz F, Zahler S, Gloe T, Issbrucker K, Unterberger P, Zaiou M, Lebherz
C, Karl A, Raake P, Pfosser A, Boekstegers P, Welsch U, Hiemstra PS, et al. An angiogenic role for the human peptide antibiotic LL-37/hCAP-18. J Clin Invest. 2003; 111:1665-1672.

11. Hirsch T, Spielmann M, Zuhaili B, Fossum M, Metzig M, Koehler T, Steinau HU, Yao F, Onderdonk AB, Steinstraesser L and Eriksson E. Human $\beta$-defensin-3 promotes wound healing in infected diabetic wounds. The Journal of Gene Medicine. 2009; 11:220-228.

12. Duplantier AJ and van Hoek ML. The Human Cathelicidin Antimicrobial Peptide LL-37 as a Potential Treatment for Polymicrobial Infected Wounds. Frontiers in immunology. 2013; 4:143.

13. Dawson RM, McAllister J and Liu CQ. Characterisation and evaluation of synthetic antimicrobial peptides against Bacillus globigii, Bacillus anthracis and Burkholderia thailandensis. International journal of antimicrobial agents. 2010; 36:359-363.

14. Westman J, Hansen FC, Olin AI, Morgelin M, Schmidtchen A and Herwald H. p33 (gC1q receptor) prevents cell damage by blocking the cytolytic activity of antimicrobial peptides. J Immunol. 2013; 191:5714-5721.

15. Ashby M, Petkova A and Hilpert K. Cationic antimicrobial peptides as potential new therapeutic agents in neonates and children: a review. Current opinion in infectious diseases. 2014; 27:258-267.

16. Hilchie AL, Wuerth $\mathrm{K}$ and Hancock RE. Immune modulation by multifaceted cationic host defense (antimicrobial) peptides. Nat Chem Biol. 2013; 9:761-768.

17. Tang YQ, Yuan J, Osapay G, Osapay K, Tran D, Miller CJ, Ouellette AJ and Selsted ME. A cyclic antimicrobial peptide produced in primate leukocytes by the ligation of two truncated alpha-defensins. Science. 1999; 286:498-502.

18. Lehrer RI, Cole AM and Selsted ME. theta-Defensins: cyclic peptides with endless potential. J Biol Chem. 2012; 287:27014-27019.

19. Cole AM, Hong T, Boo LM, Nguyen T, Zhao C, Bristol G, Zack JA, Waring AJ, Yang OO and Lehrer RI. Retrocyclin: a primate peptide that protects cells from infection by $\mathrm{T}$ and M-tropic strains of HIV-1. Proc Natl Acad Sci U S A. 2002; 99:1813-1818.

20. Jarczak J, Kosciuczuk EM, Lisowski P, Strzalkowska N, Jozwik A, Horbanczuk J, Krzyzewski J, Zwierzchowski L and Bagnicka E. Defensins: natural component of human innate immunity. Human immunology. 2013; 74:10691079.

21. Wang W, Cole AM, Hong T, Waring AJ and Lehrer RI. Retrocyclin, an antiretroviral theta-defensin, is a lectin. J Immunol. 2003; 170:4708-4716.

22. Cole AL, Herasimtschuk A, Gupta P, Waring AJ, Lehrer RI and Cole AM. The retrocyclin analogue RC-101 prevents human immunodeficiency virus type 1 infection of a model human cervicovaginal tissue construct. Immunology. 2007; 121:140-145. 
23. Tran D, Tran P, Roberts K, Osapay G, Schaal J, Ouellette A and Selsted ME. Microbicidal properties and cytocidal selectivity of rhesus macaque theta defensins. Antimicrob Agents Chemother. 2008; 52:944-953.

24. Kokryakov VN, Harwig SS, Panyutich EA, Shevchenko AA, Aleshina GM, Shamova OV, Korneva HA and Lehrer RI. Protegrins: leukocyte antimicrobial peptides that combine features of corticostatic defensins and tachyplesins. FEBS Lett. 1993; 327:231-236.

25. Steinberg DA, Hurst MA, Fujii CA, Kung AH, Ho JF, Cheng FC, Loury DJ and Fiddes JC. Protegrin-1: a broadspectrum, rapidly microbicidal peptide with in vivo activity. Antimicrob Agents Chemother. 1997; 41:17381742.

26. Yasin B, Harwig SS, Lehrer RI and Wagar EA. Susceptibility of Chlamydia trachomatis to protegrins and defensins. Infect Immun. 1996; 64:709-713.

27. Qu XD, Harwig SS, Shafer WM and Lehrer RI. Protegrin structure and activity against Neisseria gonorrhoeae. Infect Immun. 1997; 65:636-639.

28. Lee SB, Li B, Jin $\mathrm{S}$ and Daniell H. Expression and characterization of antimicrobial peptides Retrocyclin-101 and Protegrin-1 in chloroplasts to control viral and bacterial infections. Plant biotechnology journal. 2011; 9:100-115.

29. Parachin NS and Franco OL. New edge of antibiotic development: antimicrobial peptides and corresponding resistance. Frontiers in microbiology. 2014; 5:147.

30. Sassi AB, Cost MR, Cole AL, Cole AM, Patton DL, Gupta $\mathrm{P}$ and Rohan LC. Formulation development of retrocyclin 1 analog RC-101 as an anti-HIV vaginal microbicide product. Antimicrob Agents Chemother. 2011; 55:2282-2289.

31. Cole AM, Patton DL, Rohan LC, Cole AL, CosgroveSweeney Y, Rogers NA, Ratner D, Sassi AB, LackmanSmith C, Tarwater P, Ramratnam B, Ruchala P, Lehrer RI, Waring AJ and Gupta P. The formulated microbicide RC101 was safe and antivirally active following intravaginal application in pigtailed macaques. PLoS One. 2010; 5:e15111.

32. Giles FJ, Miller CB, Hurd DD, Wingard JR, Fleming TR, Sonis ST, Bradford WZ, Pulliam JG, Anaissie EJ, Beveridge RA, Brunvand MM, Martin PJ and Investigators P-CT. A phase III, randomized, double-blind, placebo-controlled, multinational trial of iseganan for the prevention of oral mucositis in patients receiving stomatotoxic chemotherapy (PROMPT-CT trial). Leukemia \& lymphoma. 2003; 44:1165-1172.

33. Trotti A, Garden A, Warde P, Symonds P, Langer C, Redman R, Pajak TF, Fleming TR, Henke M, Bourhis J, Rosenthal DI, Junor E, Cmelak A, Sheehan F, Pulliam J, Devitt-Risse $\mathrm{P}$, et al. A multinational, randomized phase III trial of iseganan $\mathrm{HCl}$ oral solution for reducing the severity of oral mucositis in patients receiving radiotherapy for head-and-neck malignancy. International journal of radiation oncology, biology, physics. 2004; 58:674-681.
34. Kollef M, Pittet D, Sanchez Garcia M, Chastre J, Fagon JY, Bonten M, Hyzy R, Fleming TR, Fuchs H, Bellm L, Mercat A, Manez R, Martinez A, Eggimann P, Daguerre M, Luyt $\mathrm{CE}$, et al. A randomized double-blind trial of iseganan in prevention of ventilator-associated pneumonia. American journal of respiratory and critical care medicine. 2006; 173:91-97.

35. Weller K, Foitzik K, Paus R, Syska W and Maurer M. Mast cells are required for normal healing of skin wounds in mice. FASEB J. 2006; 20:2366-2368.

36. Marshall JS and Jawdat DM. Mast cells in innate immunity. J Allergy Clin Immunol. 2004; 114:21-27.

37. Gekara NO and Weiss S. Mast cells initiate early antiListeria host defences. Cellular microbiology. 2008; 10:225-236.

38. Thakurdas SM, Melicoff E, Sansores-Garcia L, Moreira DC, Petrova Y, Stevens RL and Adachi R. The mast cellrestricted tryptase mMCP-6 has a critical immunoprotective role in bacterial infections. J Biol Chem. 2007; 282:2080920815.

39. Malaviya R, Navara C and Uckun FM. Role of Janus kinase 3 in mast cell-mediated innate immunity against gramnegative bacteria. Immunity. 2001; 15:313-321.

40. Douaiher J, Succar J, Lancerotto L, Gurish MF, Orgill DP, Hamilton MJ, Krilis SA and Stevens RL. Development of mast cells and importance of their tryptase and chymase serine proteases in inflammation and wound healing. Advances in immunology. 2014; 122:211-252.

41. Abraham SN and St John AL. Mast cell-orchestrated immunity to pathogens. Nature reviews Immunology. 2010; 10:440-452.

42. McLachlan JB, Shelburne CP, Hart JP, Pizzo SV, Goyal R, Brooking-Dixon R, Staats HF and Abraham SN. Mast cell activators: a new class of highly effective vaccine adjuvants. Nat Med. 2008; 14:536-541.

43. Malaviya R and Georges A. Regulation of mast cellmediated innate immunity during early response to bacterial infection. Clinical reviews in allergy \& immunology. 2002; 22:189-204.

44. Echtenacher B, Mannel DN and Hultner L. Critical protective role of mast cells in a model of acute septic peritonitis [see comments]. Nature. 1996; 381:75-77.

45. Robas N, Mead E and Fidock M. MrgX2 is a high potency cortistatin receptor expressed in dorsal root ganglion. J Biol Chem. 2003; 278:44400-44404.

46. Tatemoto K, Nozaki Y, Tsuda R, Konno S, Tomura K, Furuno M, Ogasawara H, Edamura K, Takagi H, Iwamura $\mathrm{H}$, Noguchi $\mathrm{M}$ and Naito T. Immunoglobulin E-independent activation of mast cell is mediated by Mrg receptors. Biochemical and biophysical research communications. 2006; 349:1322-1328.

47. Fujisawa D, Kashiwakura J, Kita H, Kikukawa Y, Fujitani Y, Sasaki-Sakamoto T, Kuroda K, Nunomura S, Hayama K, Terui T, Ra C and Okayama Y. Expression of Mas-related 
gene $\mathrm{X} 2$ on mast cells is upregulated in the skin of patients with severe chronic urticaria. J Allergy Clin Immunol. 2014; 134:622-633 e629.

48. Coffelt SB, Tomchuck SL, Zwezdaryk KJ, Danka ES and Scandurro AB. Leucine leucine-37 uses formyl peptide receptor-like 1 to activate signal transduction pathways, stimulate oncogenic gene expression, and enhance the invasiveness of ovarian cancer cells. Molecular cancer research : MCR. 2009; 7:907-915.

49. Li Y, Cai L, Wang H, Wu P, Gu W, Chen Y, Hao H, Tang K, Yi P, Liu M, Miao S and Ye D. Pleiotropic regulation of macrophage polarization and tumorigenesis by formyl peptide receptor-2. Oncogene. 2011; 30:3887-3899.

50. Pundir P, Catalli A, Leggiadro C, Douglas SE and Kulka M. Pleurocidin, a novel antimicrobial peptide, induces human mast cell activation through the FPRL1 receptor. Mucosal immunology. 2014; 7:177-187.

51. Ahamed J, Haribabu B and Ali H. Cutting edge: Differential regulation of chemoattractant receptor-induced degranulation and chemokine production by receptor phosphorylation. J Immunol. 2001; 167:3559-3563.

52. Ali H, Ahamed J, Hernandez-Munain C, Baron JL, Krangel MS and Patel DD. Chemokine production by G proteincoupled receptor activation in a human mast cell line: roles of extracellular signal-regulated kinase and NFAT. J Immunol. 2000; 165:7215-7223.

53. McNeil BD, Pundir P, Meeker S, Han L, Undem BJ, Kulka $\mathrm{M}$ and Dong X. Identification of a mast-cell-specific receptor crucial for pseudo-allergic drug reactions. Nature. 2015; 519:237-241.

54. Ramkumar V, Stiles GL, Beaven MA and Ali H. The A3 adenosine receptor is the unique adenosine receptor which facilitates release of allergic mediators in mast cells. J Biol Chem. 1993; 268:16887-16890.

55. Ahamed J and Ali H. Distinct roles of receptor phosphorylation, G protein usage, and mitogen-activated protein kinase activation on platelet activating factorinduced leukotriene C(4) generation and chemokine production. J Biol Chem. 2002; 277:22685-22691.

56. Kashem SW, Subramanian H, Collington SJ, Magotti $\mathrm{P}$, Lambris JD and Ali H. G protein coupled receptor specificity for C3a and compound 48/80-induced degranulation in human mast cells: roles of Masrelated genes MrgX1 and MrgX2. European journal of pharmacology. 2011; 668:299-304.

57. Ruhlman T, Verma D, Samson N and Daniell H. The role of heterologous chloroplast sequence elements in transgene integration and expression. Plant physiology. 2010; 152:2088-2104.

58. Kanagaraj AP, Verma D and Daniell H. Expression of dengue-3 premembrane and envelope polyprotein in lettuce chloroplasts. Plant molecular biology. 2011; 76:323-333.

59. Verma D, Kanagaraj A, Jin S, Singh ND, Kolattukudy PE and Daniell H. Chloroplast-derived enzyme cocktails hydrolyse lignocellulosic biomass and release fermentable sugars. Plant biotechnology journal. 2010; 8:332-350.

60. Kwon KC, Nityanandam R, New JS and Daniell H. Oral delivery of bioencapsulated exendin-4 expressed in chloroplasts lowers blood glucose level in mice and stimulates insulin secretion in beta-TC6 cells. Plant biotechnology journal. 2013; 11:77-86.

61. Verma D, Moghimi B, LoDuca PA, Singh HD, Hoffman BE, Herzog RW and Daniell H. Oral delivery of bioencapsulated coagulation factor IX prevents inhibitor formation and fatal anaphylaxis in hemophilia B mice. Proc Natl Acad Sci U S A. 2010; 107:7101-7106.

62. Sherman A, Su J, Lin S, Wang X, Herzog RW and Daniell H. Suppression of inhibitor formation against FVIII in a murine model of hemophilia A by oral delivery of antigens bioencapsulated in plant cells. Blood. 2014; 124:1659-1668.

63. Kohli N, Westerveld DR, Ayache AC, Verma A, Shil P, Prasad T, Zhu P, Chan SL, Li Q and Daniell H. Oral delivery of bioencapsulated proteins across blood-brain and blood-retinal barriers. Mol Ther. 2014; 22:535-546.

64. Shenoy V, Kwon KC, Rathinasabapathy A, Lin S, Jin G, Song C, Shil P, Nair A, Qi Y, Li Q, Francis J, Katovich MJ, Daniell $\mathrm{H}$ and Raizada MK. Oral delivery of Angiotensin-converting enzyme 2 and Angiotensin-(1-7) bioencapsulated in plant cells attenuates pulmonary hypertension. Hypertension. 2014; 64:1248-1259.

65. Shil PK, Kwon KC, Zhu P, Verma A, Daniell H and Li Q. Oral delivery of ACE2/Ang-(1-7) bioencapsulated in plant cells protects against experimental uveitis and autoimmune uveoretinitis. Mol Ther. 2014; 22:2069-2082.

66. Kwon KC, Verma D, Singh ND, Herzog R and Daniell H. Oral delivery of human biopharmaceuticals, autoantigens and vaccine antigens bioencapsulated in plant cells. Advanced drug delivery reviews. 2013; 65:782-799.

67. Lakshmi PS, Verma D, Yang X, Lloyd B and Daniell H. Low cost tuberculosis vaccine antigens in capsules: expression in chloroplasts, bio-encapsulation, stability and functional evaluation in vitro. PLoS One. 2013; 8:e54708.

68. Boyhan D and Daniell H. Low-cost production of proinsulin in tobacco and lettuce chloroplasts for injectable or oral delivery of functional insulin and C-peptide. Plant biotechnology journal. 2011; 9:585-598.

69. Arlen PA, Falconer R, Cherukumilli S, Cole A, Cole AM, Oishi KK and Daniell H. Field production and functional evaluation of chloroplast-derived interferon-alpha $2 \mathrm{~b}$. Plant biotechnology Journal. 2007; 5:511-525.

70. Kohli N, Westerveld DR, Ayache AC, Verma A, Shil P, Prasad T, Zhu P, Chan SL, Li QH and Daniell H. Oral Delivery of Bioencapsulated Proteins Across Blood-Brain and Blood-Retinal Barriers. Mol Ther. 2014; 22:535-546.

71. Mager I, Roberts TC, Wood MJA and Andaloussi SEL. From Gut to Brain: Bioencapsulated Therapeutic Protein Reduces Amyloid Load Upon Oral Delivery. Mol Ther. 2014; 22:485-486. 
72. Shil PK, Kwon KC, Zhu P, Verma A, Daniell $\mathrm{H}$ and $\mathrm{Li}$ QH. Oral Delivery of ACE2/Ang-(1-7) Bioencapsulated in Plant Cells Protects against Experimental Uveitis and Autoimmune Uveoretinitis. Mol Ther. 2014; 22:2069-2082.

73. Wang XM, Su J, Sherman A, Rogers GL, Liao GX, Hoffman BE, Leong KW, Terhorst C, Daniell H and Herzog RW. Plant-based oral tolerance to hemophilia therapy employs a complex immune regulatory response including LAP(+)CD4(+) T cells. Blood. 2015; 125:2418-2427.

74. Millan AFS, Ortigosa SM, Hervas-Stubbs S, CorralMartinez P, Segui-Simarro JM, Gaetan J, Coursaget P and Veramendi J. Human papillomavirus L1 protein expressed in tobacco chloroplasts self-assembles into virus-like particles that are highly immunogenic. Plant biotechnology Journal. 2008; 6:427-441.

75. Kanagaraj AP, Verma D and Daniell H. Expression of dengue-3 premembrane and envelope polyprotein in lettuce chloroplasts. Plant Mol Biol. 2011; 76:323-333.

76. Sanz-Barrio R, Fernandez-San Millan A, Corral-Martinez P, Segui-Simarro JM and Farran I. Tobacco plastidial thioredoxins as modulators of recombinant protein production in transgenic chloroplasts. Plant biotechnology Journal. 2011; 9:639-650.

77. Tsvetanova NG, Irannejad R and von Zastrow M. G Proteincoupled Receptor (GPCR) Signaling via Heterotrimeric G Proteins from Endosomes. J Biol Chem. 2015; 290:66896696.

78. Ferry X, Brehin S, Kamel R and Landry Y. G proteindependent activation of mast cell by peptides and basic secretagogues. Peptides. 2002; 23:1507.

79. Li M, Chen Q, Tang R, Shen Y and Liu WD. The expression of beta-defensin-2, 3 and LL-37 induced by Candida albicans phospholipomannan in human keratinocytes. J Dermatol Sci. 2011; 61:72-75.

80. Hertz CJ, Wu Q, Porter EM, Zhang YJ, Weismuller KH, Godowski PJ, Ganz T, Randell SH and Modlin RL. Activation of Toll-like receptor 2 on human tracheobronchial epithelial cells induces the antimicrobial peptide human beta defensin-2. J Immunol. 2003; 171:68206826.

81. Hazlett L and Wu M. Defensins in innate immunity. Cell and tissue research. 2011;343:175-188.

82. Chen X, Niyonsaba F, Ushio H, Hara M, Yokoi H, Matsumoto K, Saito H, Nagaoka I, Ikeda S, Okumura K and Ogawa H. Antimicrobial peptides human beta-defensin (hBD)-3 and hBD-4 activate mast cells and increase skin vascular permeability. European journal of immunology. 2007; 37:434-444.

83. Shelburne CP, Nakano H, St John AL, Chan C, McLachlan JB, Gunn MD, Staats HF and Abraham SN. Mast cells augment adaptive immunity by orchestrating dendritic cell trafficking through infected tissues. Cell host \& microbe. 2009; 6:331-342.

84. Galli SJ, Nakae S and Tsai M. Mast cells in the development of adaptive immune responses. Nat Immunol. 2005; 6:135142 .

85. Jawdat DM, Rowden G and Marshall JS. Mast cells have a pivotal role in TNF-independent lymph node hypertrophy and the mobilization of Langerhans cells in response to bacterial peptidoglycan. J Immunol. 2006; 177:1755-1762.

86. Amaral MM, Davio C, Ceballos A, Salamone G, Canones $\mathrm{C}$, Geffner J and Vermeulen M. Histamine improves antigen uptake and cross-presentation by dendritic cells. J Immunol. 2007; 179:3425-3433.

87. McGowen AL, Hale LP, Shelburne CP, Abraham SN and Staats HF. The mast cell activator compound $48 / 80$ is safe and effective when used as an adjuvant for intradermal immunization with Bacillus anthracis protective antigen. Vaccine. 2009; 27:3544-3552.

88. Ramos R, Silva JP, Rodrigues AC, Costa R, Guardao L, Schmitt F, Soares R, Vilanova M, Domingues L and Gama M. Wound healing activity of the human antimicrobial peptide LL37. Peptides. 2011; 32:1469-1476.

89. Kirshenbaum AS, Akin C, Wu Y, Rottem M, Goff JP, Beaven MA, Rao VK and Metcalfe DD. Characterization of novel stem cell factor responsive human mast cell lines LAD 1 and 2 established from a patient with mast cell sarcoma/leukemia; activation following aggregation of F\&RI or Fc $\gamma R I$. Leuk Res. 2003; 27:677-682.

90. Ali H, Richardson RM, Tomhave ED, DuBose RA, Haribabu B and Snyderman R. Regulation of stably transfected platelet activating factor receptor in RBL$2 \mathrm{H} 3$ cells. Role of multiple $\mathrm{G}$ proteins and receptor phosphorylation. J Biol Chem. 1994; 269:24557-24563.

91. Skosyrev VS, Rudenko NV, Yakhnin AV, Zagranichny VE, Popova LI, Zakharov MV, Gorokhovatsky AY and Vinokurov LM. EGFP as a fusion partner for the expression and organic extraction of small polypeptides. Protein expression and purification. 2003; 27:55-62.

92. Steinberg DA and Lehrer RI. Designer assays for antimicrobial peptides. Disputing the "one-size-fits-all" theory. Methods Mol Biol. 1997; 78:169-186. 